Research Article

\title{
Removal of Tetracycline from Aqueous Solution Using Nanocomposite Based on Polyanion-Modified Laterite Material
}

\author{
Thi Hau Vu, Thi Mai Viet Ngo ${ }^{D}$, Thi Tu Anh Duong, Thi Hien Lan Nguyen, \\ Xuan Truong Mai, Thi Hong Nguyet Pham, Thi Phuong Le, and Thi Hue Tran \\ Thai Nguyen University of Education, Thai Nguyen University, 20 Luong Ngoc Quyen, Quang Trung, Thai Nguyen, Vietnam \\ Correspondence should be addressed to Thi Mai Viet Ngo; vietntm@tnue.edu.vn
}

Received 13 October 2020; Revised 17 November 2020; Accepted 30 November 2020; Published 11 December 2020

Academic Editor: Thi Anh Huong Nguyen

Copyright ( $\odot 2020$ Thi Hau Vu et al. This is an open access article distributed under the Creative Commons Attribution License, which permits unrestricted use, distribution, and reproduction in any medium, provided the original work is properly cited.

\begin{abstract}
This work investigated the removal of antibiotic tetracycline (TC) from wastewater using nanocomposite material based on laterite modified with polyanion, polystyrene sulfonate (PSS). The effective factors influenced on the TC removal using nanocomposite PSS-modified laterite (NCPML) were optimized and found to be $\mathrm{pH} 4$, solid-liquid ratio $5 \mathrm{mg} / \mathrm{mL}$, and contact time $180 \mathrm{~min}$. The highest removal of TC reached about $88 \%$ under the optimum adsorption conditions. The adsorption isotherm and kinetics of TC adsorption onto NCPML were in good agreement with the Langmuir and pseudo-second-order models, respectively. The characteristics of the NCPML material before and after TC adsorption were examined by zeta $(\zeta)$ potential measurements, Brunauer-Emmett-Teller (BET) method, and Fourier transform infrared spectroscopy (FT-IR). The TC adsorption onto NCPML was induced by electrostatic interaction, hydrogen bonding, and diffusion interaction. The TC removal from wastewater was approximately $94 \%$ while efficiency still reached $66 \%$ after five regenerations. Our research reveals that NCPML is a high-performance adsorbent for TC removal from wastewater.
\end{abstract}

\section{Introduction}

Nanocomposite material based on polymer-coated substrate is a hybrid adsorbent for pollutants removal [1-3]. Basically, the polycation adsorption onto negatively charged clays is forming the composite that is widely used in environmental remediation $[4,5]$. Various organic contaminants such as herbicides [6], organic dyes [7], heavy metals [8], and antibiotics [9] were removed using these kinds of composite. On the contrary, polyanion adsorption onto positively charged minerals as a new composite material for antibiotics removal has not been reported.

In recent years, aquaculture in Vietnam has progressed on a large scale and production. However, aquaculture and fish processing have produced pollutants to the environment, especially to water sources. The wastewater from aquaculture contains decomposing surplus food sources, chemicals, and antibiotics. Many families of antibiotics are used for bacteria treatment [10]. Tetracycline (TC) is a big antibiotic group that is widely used to treat animal and human diseases as well as an antibacterial in aquaculture activity [11, 12]. In TC group, tetracycline (TC), whose molecular structure is shown in Figure 1, is the most common antibiotic. The TC is widely used to not only treat diseases of animals but also used as a part of animal feed to enhance effective growth [13]. High amounts of TC are released into the aqueous solution that can cause serious problems for animals and human health [14, 15]. Thus, various techniques are investigated to eliminate TC [16].

The well-known methods for TC removal include adsorption [13, 17-19], advanced oxidation [20], and degradation using catalyst [21] and membrane bioreactor [22-24]. It is evident that adsorption is a popular method used in developing countries because many minerals or natural soils can be fabricated or modified slow-cost adsorbents $[17,25-27]$. Adsorption is known as a green technique in which fewer chemicals are used [28]. In addition, adsorption is a versatile method due to easy modification and regulation of charged surface. On the contrary, low selectivity with common adsorbent is a disadvantage of the adsorption 


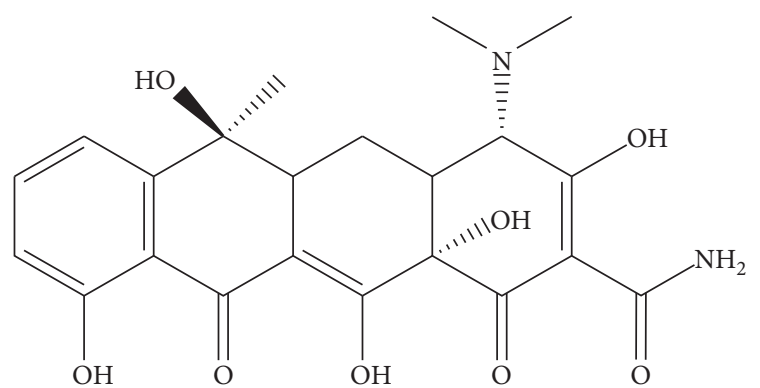

Figure 1: Molecular structure of TC.

technique [29]. Therefore, a new adsorbent for pollutants removal is always a great topic of interest for many scientists. To the best of our knowledge, the removal of TC by nanocomposite-based polyanion-coated laterite soil has not been investigated $[16,30]$.

Laterite is common in tropical countries like Vietnam. The material was modified by an anionic surfactant sodium dodecyl sulfate (SDS) for removal of different pollutants [31-33]. However, using polyanion such as polystyrene sulfonate (PSS) to modify laterite soil for TC removal is still a new study.

The interfacial and physicochemical methods including $\zeta$ potential measurements, Brunauer-Emmett-Teller (BET), and Fourier transform infrared spectroscopy (FT-IR) were employed to evaluate the changes in material characterization before and after TC adsorption. The isotherms and kinetics of TC onto NCPML were systematically investigated by experimental consideration and theoretical models. The reuse of NCPML and the application for TC removal in actual wastewater were also investigated in this work.

\section{Materials and Methods}

2.1. Materials. We collected the raw laterite at Thach That district, Hanoi, Vietnam. The bare laterite was treated as in our previously published papers [32, 33].

A strong polyelectrolyte with a negative charge, polystyrene sulfonate (PSS) with purity $\geq 98 \%$, was purchased from Scharlau (Spain, EU). Tetracycline (TC) with purity $\geq 95 \%$ was supplied from Sigma-Aldrich (USA). We used monovalent salt of $\mathrm{NaCl}$ (p.A, Merck) to study the influence of ionic strength on the adsorption. In addition, strong acid $\mathrm{HCl}$ and strong base $\mathrm{NaOH}$ (p.A, Merck) were used to regulate the $\mathrm{pH}$ of all solutions. A pH meter (Presisa 900-Switzerland) using a commercial glass electrode was used to monitor $\mathrm{pH}$ for solutions. The deionized water was used and prepared for the aqueous solutions in this investigation.

\subsection{Nanocomposite Material Based on PSS-Modified Laterite.} Nanocomposite material was fabricated on the basis of PSSmodified laterite under the optimum condition. Firstly, the laterite was thoroughly mixed by shaking with $100 \mathrm{mg} / \mathrm{L}$ of PSS in $50 \mathrm{mM} \mathrm{NaCl}$ and the solid-liquid ratio $5 \mathrm{mg} / \mathrm{mL}$ at $\mathrm{pH}$ 4 for $150 \mathrm{~min}$. Then, the solid material was separated by centrifuging before cleaning it with deionized water. The obtained nanocomposite-based PSS-modified laterite was formed and called as NCPML.

2.3. Adsorption Studies. Adsorption by the batch technique was used to study TC removal using NCPML. First of all, the stock solutions of TC with a concentration of $100 \mathrm{mg} / \mathrm{L}$ were prepared by dissolving the accuracy of TC amount in methanol and deionized water. Then, the stock solutions were taken for dilution to give a daily solution.

Different amounts of adsorbent were mixed with $25 \mathrm{~mL}$ TC solution of given concentrations in $100 \mathrm{~mL}$ Erlenmeyer flasks at $25 \pm 2^{\circ} \mathrm{C}$. Some important factors affecting the TC removal such as contact time, adsorbent dosages, $\mathrm{pH}$ of solution, and ionic strength were systematically investigated. All concentrations of TC in aqueous solutions were examined by the ultraviolet visible (UV-Vis) method at $277.4 \mathrm{~nm}$ using a UV-1700 spectrometer (Shimadzu, Japan). The TC removal efficiency was calculated by the following equation:

$$
\text { removal efficiency }(\%)=\frac{C_{i}-C_{f}}{C_{i}} \times 100 \%,
$$

where $C_{i}$ and $C_{f}$ are the initial and final concentrations of TC $(\mathrm{mg} / \mathrm{L})$.

The following equation was used to determine the TC adsorption capacity onto NCPML material:

$$
\Gamma=\frac{C_{i}-C_{e}}{m} \times V,
$$

where $\Gamma$ is denoted as adsorption capacity of TC $(\mathrm{mg} / \mathrm{g}), C_{e}$ is the TC equilibrium concentration $(\mathrm{mg} / \mathrm{L}), V$ is volume of solution (L), and $m$ is the adsorbent mass $(\mathrm{g})$.

2.4. Characterization Methods. The $\zeta$ potential measurements and Brunauer-Emmett-Teller (BET) method were employed to characterize NCPML material before and after TC adsorption.

Zeta $(\zeta)$ potential was conducted using a Nano ZS Zetasizer (Malvern, UK). The $\zeta$ potential was calculated by the following equation [34]:

$$
\zeta=\frac{u_{e} \eta}{\varepsilon_{r s} \varepsilon_{0}}
$$

where $u_{e}$ is the electrophoretic mobility $\left(\mu \mathrm{ms}^{-1} / \mathrm{V} \cdot \mathrm{cm}^{-1}\right), \eta$ is the dynamic viscosity of the liquid $(\mathrm{mPa} \cdot \mathrm{s}), \varepsilon_{0}$ is the electric permittivity of vacuum $\left(8.854 \times 10^{-12} \cdot \mathrm{F} / \mathrm{m}\right)$, and $\varepsilon_{r s}$ is the relative permittivity constant of the electrolyte solution.

The BET method is based on $\mathrm{N}_{2}$ adsorption and desorption isotherms on the material to determine the specific surface area of the NCPML before and after TC adsorption using a surface area analyzer, Micromeritics (TriStar 3000, Norcross, GA, USA).

Furthermore, we also used the Fourier transform infrared (FT-IR) spectroscopy to check the different vibration groups of the NCPML before and after TC adsorption. The FT-IR spectra were conducted by using Affinity-1S (Shimadzu, Japan). 


\subsection{Adsorption Isotherm and Kinetic Modeling}

2.5.1. Adsorption Isotherm Modeling. It is necessary to apply a suitable model to deeply understand the mechanisms of the adsorption process. The Langmuir and Freundlich models were applied to fit TC isotherms NCPML.

The Langmuir isotherm equation is [35] as follows:

$$
\frac{C_{e}}{q_{e}}=\frac{C_{e}}{q_{\max }}+\frac{1}{q_{\max } K_{L}},
$$

where $K_{L}(\mathrm{~L} / \mathrm{g})$ is the Langmuir constant, $q_{\max }(\mathrm{mg} / \mathrm{g})$ is the maximum amount, and $q_{e}(\mathrm{mg} / \mathrm{g})$ is the equilibrium amount of TC.

The equation described by the Freundlich model [36] is given in the following equation:

$$
\ln q_{e}=\ln K_{F}+\frac{1}{n} \ln C_{e},
$$

where the Freundlich constant is $K_{F}\left(\mathrm{mg}^{n-1} \mathrm{~L}^{n} / \mathrm{g}\right)$ and the intensity of the adsorption is $1 / n$.

2.5.2. Adsorption Kinetic Modeling. The pseudo-first-order and pseudo-second-order models are used in the present study.

The kinetic model of pseudo-first-order is

$$
\log \left(q_{e}-q_{t}\right)=\log q_{e}-\frac{k_{1, k}}{2.303} t
$$

The kinetic model of pseudo-second-order described by the following equation:

$$
\frac{t}{q_{t}}=\frac{1}{k_{2, k} \cdot q_{e}^{2}}+\frac{1}{q_{e}} t,
$$

where $q_{e}$ and $q_{t}(\mathrm{mg} / \mathrm{g})$ are adsorption capacities of TC onto NCPML at equilibrium and time $t$, respectively, and $k_{1, k}(1 /$ $\min )$ and $k_{2, k}(\mathrm{~g} / \mathrm{mg} \cdot \mathrm{min})$ are reaction rate constants for pseudo-first-order and pseudo-second-order adsorption kinetics, respectively.

\section{Results and Discussion}

\subsection{Effective Conditions for TC Adsorption onto NCPML}

3.1.1. Effect of $p H$. The effect of $\mathrm{pH}$ on the TC removal using NCPML is shown in Figure 2. The experiment of $\mathrm{pH}$ effect was conducted in the $\mathrm{pH}$ range of 3-9 to find out the best $\mathrm{pH}$ for TC removal using NCPML.

Figure 2 shows that the TC removal using NCPML reached the maximum at $\mathrm{pH} 4$ and then decreased from $\mathrm{pH}$ 5 to 9. The $\mathrm{p} K_{a}$ values of TC are 3.3, 7.7, and 9.7; therefore, in the range of $\mathrm{pH} \mathrm{3-9,} \mathrm{TC} \mathrm{exists} \mathrm{in} \mathrm{the} \mathrm{cationic,} \mathrm{zwitterionic,}$ or anionic forms in aqueous solution under $\mathrm{pH} 3.3$, in the range of $\mathrm{pH} 3.3-7.7$, and above $\mathrm{pH}$ 7.7, respectively [37]. At $\mathrm{pH} 4$, the negative charge surface of NCPML is convenient for attaching the cationic and zwitterionic species of TC. This result is similar to the previous report by other researchers [38]. When increasing the $\mathrm{pH}$ value from 5 to 8 , the TC removal decreased because the negative part of the
TC zwitterionic form increased. However, at $\mathrm{pH} \geq 8$, the decrease in adsorption was observed due to the increase in electrical repulsion force between the anionic TC and the negatively charged NCPML surface. At $\mathrm{pH} \mathrm{3,} \mathrm{a} \mathrm{part} \mathrm{of} \mathrm{the}$ metal oxide of laterite may be dissolved, so TC removal also decreased. The $\mathrm{pH} 4$ is therefore selected and kept for TC removal using NCPML.

3.1.2. Effect of Contact Time. The influence of contact time on TC removal using NCPML is shown in Figure 3. The contact time increased from 15 to $240 \mathrm{~min}$. Figure 3 indicates that TC removal using NCPML grew up from 61 to $87 \%$ when increasing time in the prior 15-180 min. When contact time is greater than $180 \mathrm{~min}$, the TC removal efficiency decreased insignificantly because of the PSS desorption from NCPML. In addition, the error bars of three replicates were the smallest at $180 \mathrm{~min}$ so that $180 \mathrm{~min}$ is the best contact time for TC removal.

3.1.3. Influence of Adsorbent Dosage. It is necessary to study the influence of adsorbent dosage to evaluate the eco-effectiveness of adsorbents. The influence of adsorbent dosage on TC removal using NCPML was investigated in the range of $1-8 \mathrm{mg} / \mathrm{mL}$ and is indicated in Figure 4 . As can be seen in Figure 4, the TC removal increased when the adsorbent dosage increased from 1 to $8 \mathrm{mg} / \mathrm{mL}$ as the result of rising the net surface charge or specific surface area of the adsorbent. The TC plateau removal efficiency was achieved at $5 \mathrm{mg} / \mathrm{mL}$ as $88 \%$ and was not changed significantly when the amount of adsorbent was above $5 \mathrm{mg} / \mathrm{mL}$. Therefore, we used $5 \mathrm{mg} / \mathrm{mL}$ NCPML for further study on TC removal.

3.1.4. Effect of Ionic Strength. Ionic strength plays an important role in the Coulombic interaction between cationic, zwitterionic, or anionic forms of TC and the negative charge of NCPML. Figure 5 shows that the TC removal efficiency increased when $\mathrm{NaCl}$ concentration increased from 0.1 to $10 \mathrm{mM}$ and decreased from 10 to $100 \mathrm{mM} \mathrm{NaCl}$. The results propose that TC removal is influenced by changing the concentration of $\mathrm{NaCl}$. To deeply understand the influence of ionic strength on TC removal using NCPML, isothermal adsorption of TC onto NCPML is systematically investigated and given below.

3.2. Adsorption Isotherms and Mechanisms of TC onto NCPML. Isothermal adsorption of TC onto NCPML at different ionic strengths in the presence of $\mathrm{NaCl}$ salt was an experimental study and fitted by Langmuir and Freundlich models (Figures 6 and 7). The main parameters of isothermal adsorption of TC onto NCPML at $25 \pm 2{ }^{\circ} \mathrm{C}$ are presented in Table 1. Table 1 and Figures 6 and 7 show that the isothermal adsorption of TC onto NCPML represented by the Langmuir model was better than the Freundlich one. The values of correlation coefficients when using Langmuir model $\left(R^{2}>0.99\right)$ were greater than that using the Freundlich one $\left(R^{2}>0.92\right)$. 


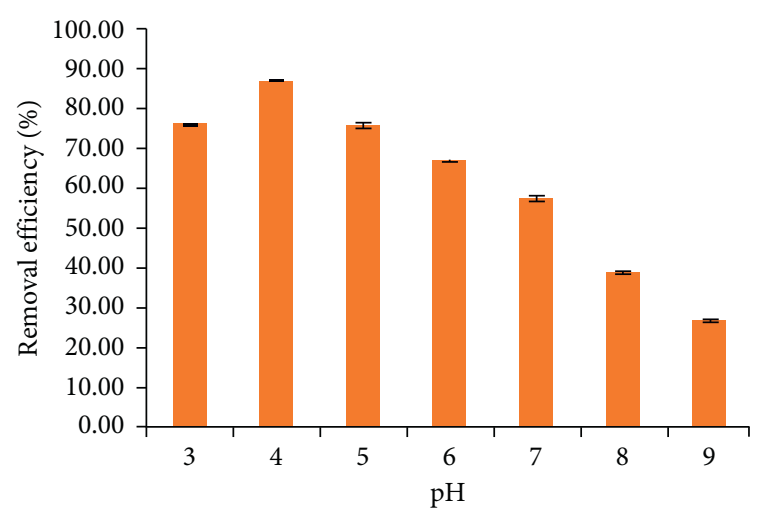

Figure 2: Effect of $\mathrm{pH}$ on the TC removal using NCPML $\left(C_{i}\right.$ $(\mathrm{TC})=10 \mathrm{mg} / \mathrm{L})$. Error bars indicate the standard deviations of three replicates.

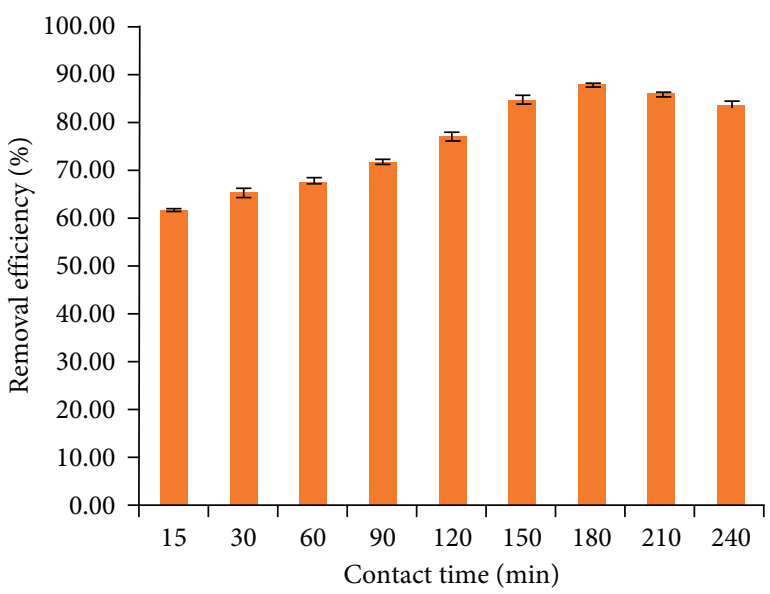

Figure 3: Effect of contact time to the TC removal onto NCPML $\left(C_{i}(\mathrm{TC})=10 \mathrm{mg} / \mathrm{L}\right), \mathrm{pH} 4$. Error bars indicate the standard deviations of three replicates.

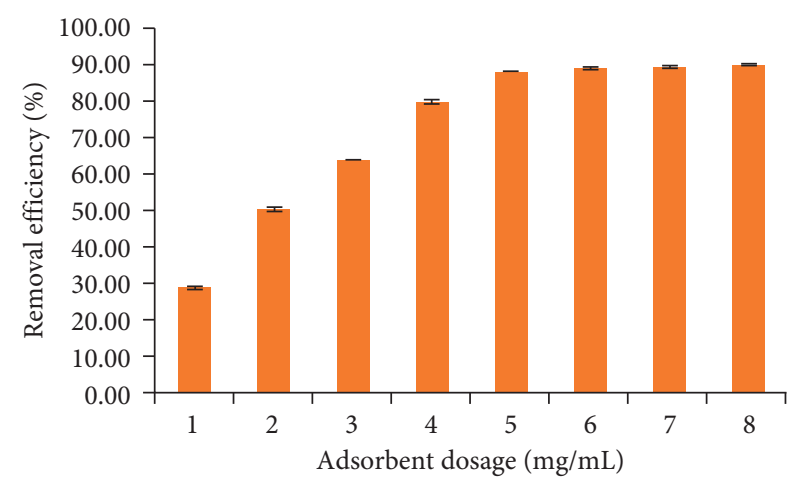

FIgURE 4: Effect of adsorbent dosage to the TC removal onto NCPML $\left(C_{i}(\mathrm{TC})=10 \mathrm{mg} / \mathrm{L}\right), \mathrm{pH} 4$, and contact time $180 \mathrm{~min}$. Error bars indicate the standard deviations of three replicates.

Figures 6 and 7 show that the ionic strength strongly influenced the adsorption isotherms of TC onto NCPML. Adsorption increased with increasing $\mathrm{NaCl}$ concentration from 1 to $10 \mathrm{mM}$ while this trend was reversed when increasing salt in the range of $10-50 \mathrm{mM}$. The higher the salt is,

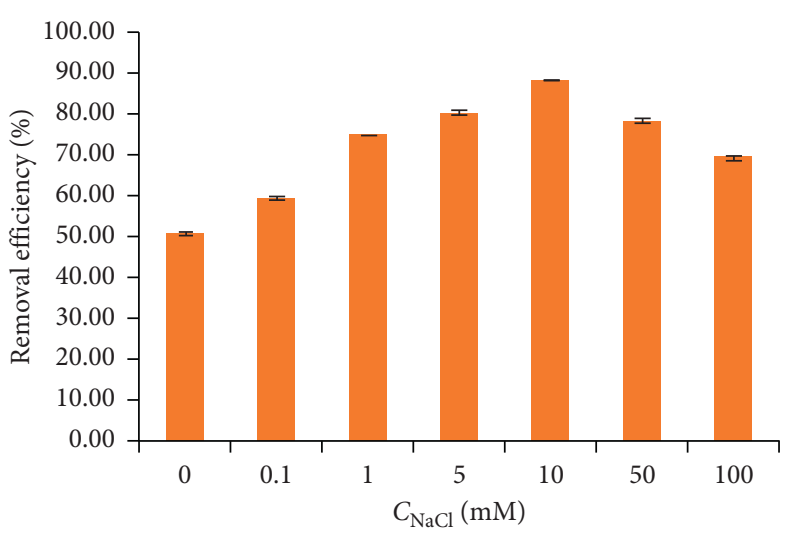

Figure 5: Effect of ionic strength to the TC removal onto NCPML $\left(C_{i}(\mathrm{TC})=10 \mathrm{mg} / \mathrm{L}\right), \mathrm{pH} 4$, contact time $180 \mathrm{~min}$, and adsorbent dosage of $5 \mathrm{mg} / \mathrm{mL}$. Error bars indicate the standard deviations of three replicates.

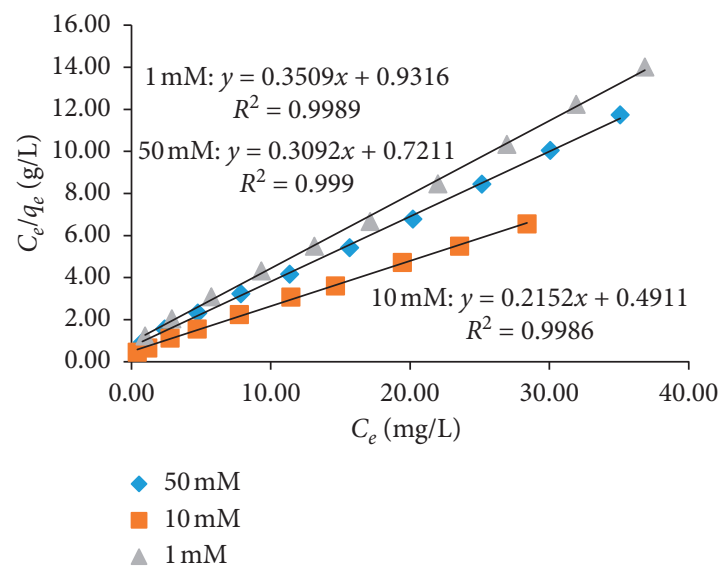

Figure 6: Adsorption isotherms of TC onto NCPML at three $\mathrm{NaCl}$ concentrations fitted by the Langmuir model.

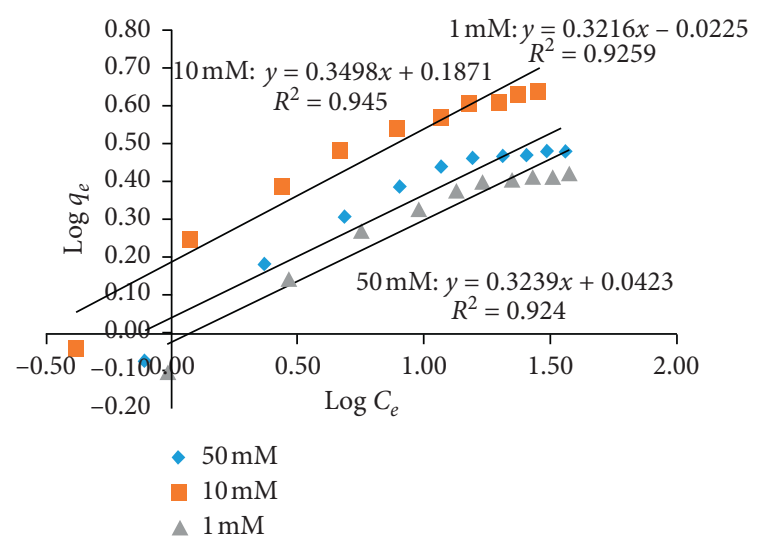

FIgURe 7: Adsorption isotherms of TC onto NCPML at three $\mathrm{NaCl}$ concentrations fitted by the Freundlich model.

the lower the electrostatic attraction induced the adsorption. It suggests that TC adsorption onto NCPML was controlled by both electrostatic and nonelectrostatic interaction at lowionic strength, but the electrostatic attraction was the main driving force for TC adsorption at high-ionic strength. 
TABLE 1: Parameters of TC adsorption isotherms onto NCPML at different $\mathrm{NaCl}$ concentrations using Langmuir and Freundlich models.

\begin{tabular}{lcccc}
\hline \multirow{2}{*}{ Isothermal model } & Parameters & \multicolumn{3}{c}{$\mathrm{NaCl}$ concentration } \\
& & 1 & 10 & 50 \\
\hline \multirow{3}{*}{ Langmuir } & $q_{\max }(\mathrm{mg} / \mathrm{g})$ & 2.85 & 4.65 & 3.23 \\
& $K_{L}(\mathrm{~L} / \mathrm{g})$ & 0.38 & 0.44 & 0.43 \\
& $R^{2}$ & 0.998 & 0.998 & 0.999 \\
\hline \multirow{3}{*}{ Freundlich } & $K_{F}$ & 0.95 & 1.54 & 1.10 \\
& $1 / n$ & 0.321 & 0.349 & 0.323 \\
& $R^{2}$ & 0.925 & 0.945 & 0.924 \\
\hline
\end{tabular}

\subsubsection{Adsorption Mechanisms of TC onto NCPML.} Adsorption mechanism of TC onto NCPML was predicted on the basis of FT-IR spectroscopy and the BET methods as well as $\zeta$ potential measurements.

Figure 8 indicates that FT-IR spectra of NCPML and NCPML after TC adsorption are similar. Nevertheless, the alkyl chain assigned at $2927.94 \mathrm{~cm}^{-1}$ of NCPML did not appear at the FT-IR spectra of NCPML after TC adsorption. Moreover, many new peaks in the wave numbers from 1200 to $2200 \mathrm{~cm}^{-1}$ appeared in the spectra of NCPML after TC adsorption. The assigned peaks at $1747.51 \mathrm{~cm}^{-1}$, $1512.19 \mathrm{~cm}^{-1}$, and $1255.66 \mathrm{~cm}^{-1}$ occurred due to the appearance of $\mathrm{C}=\mathrm{O}$ stretching, $\mathrm{O}-\mathrm{H}$ deformation, and $\mathrm{NH}_{2}$ bending, respectively [39]. The FT-IR spectra show the occurrence of TC on NCPML surface via hydrophobic interactions between carbon chains of TC and natural organic matter of NCPML.

Figure 9 shows the BET results of NCPML before and after TC adsorption. As can be seen in Figure 9, the specific surface area of NCPML decreased about $15 \mathrm{~m}^{2} / \mathrm{g}$ after TC adsorption (a decrease from $42.39 \mathrm{~m}^{2} / \mathrm{g}$ to $27.51 \mathrm{~m}^{2} / \mathrm{g}$ ). The average pore width of PSS-modified laterite which was examined by using the Barrett-Joyner-Halenda (BJH) model [40] to the $\mathrm{N}_{2}$ adsorption and desorption isotherms was 15.2 and $12.6 \mathrm{~nm}$, respectively. These pores were easily determined by $\mathrm{N}_{2}$-BET (BJH) method demonstrated that our material is a nanocomposite. After TC adsorption, the average pore decreased and was found to be $10 \mathrm{~nm}$. The BET results indicate that TC molecules were successfully taken up on NCPML.

The $\zeta$ potential is a powerful tool to evaluate the charging behavior of various materials through the adsorption technique by many researchers [41-44]. In our research, we also used the $\zeta$ potential for the purpose of confirmation of the TC adsorption mechanism onto NCPML. The $\zeta$ potential of laterite, laterite-modified PSS (NCPML), and lateritemodified PSS after TC adsorption was measured at $\mathrm{pH} 4$. Figure 10 shows that the $\zeta$ potential of raw laterite was positive $(\zeta=6.49 \mathrm{mV})$, and the $\zeta$ potential of NCPML was negative due to the presence of PSS molecules $(\zeta=-12.0 \mathrm{mV})$. After TC adsorption, the NCPML was almost noncharged with the $\zeta$ potential of $0.121 \mathrm{mV}$. The $\zeta$ potential measurements results indicated that the adsorption is controlled by Coulombic interaction between positive and zwitterionic species of TC and negatively charged NCPML surface.
3.2.2. Adsorption Kinetics of TC onto NCPML. In this section, we studied the adsorption kinetics of TC onto NCPML with different TC concentrations. The data for pseudo-first-order and pseudo-second-order models are presented in Table 2.

Table 2 shows that the pseudo-second-order is better than the pseudo-first-order, expressing by the higher correlation coefficients $\left(R^{2}\right)$ for pseudo-second-order at all TC concentrations. Moreover, the calculated $q_{e}$ values by the pseudo-second-order $(1.81,3.56$, and $5.25 \mathrm{mg} / \mathrm{g}$ for initial TC concentration of 10,25 , and $50 \mathrm{mg} / \mathrm{L}$, respectively) are similar to experimental ones $(1.76,3.46$, and $5.11 \mathrm{mg} / \mathrm{g}$ for 10,25 , and $50 \mathrm{mg} / \mathrm{L}$, respectively). It implies that kinetic adsorption of TC onto NCPML agreed well with the pseudosecond-order model.

3.3. Adsorptive Removal of TC onto Laterite with and without Modification by PSS. Removal efficiency of TC onto laterite with and without modification by PSS is presented in Figure 11. Figure 11 shows that the removal of TC, in which TC initial concentration is $10 \mathrm{mg} / \mathrm{L}$ in $10 \mathrm{mM} \mathrm{NaCl}$ and $\mathrm{pH} 4$ increases from $66.67 \%$ to $87.09 \%$ after surface modification of laterite by PSS. The negative charge of laterite after surface modification enhanced the TC removal efficiency through electrostatic attraction between the positive and zwitterionic species of TC and the negatively charged NCPML surface. The result denotes that laterite-modified PSS is more effective than laterite soil in TC removal.

3.4. Reuse Potential of NCPML. It is necessary to investigate the regeneration of materials to evaluate the stability and reusable potential. For the material recovery procedure, we conducted the experiment by the following steps. First of all, the NCPML was desorbed by $0.1 \mathrm{M} \mathrm{NaOH}$ and $0.1 \mathrm{M} \mathrm{HCl}$ after TC adsorption at a concentration of $10 \mathrm{mg} / \mathrm{L}$. Then, we used a centrifugal machine to separate the NCPML and liquid. After that, the NCPML was washed with ultrapure water many times to reach the $\mathrm{pH}$ neutral. In the next step, the NCPML was reactivated again with PSS residual (Section 2.2.). Finally, the NCPML was used again to remove $10 \mathrm{mg} / \mathrm{L}$ TC under the best conditions (Section 3.1.). The reuse of NCPML material by using $\mathrm{HCl}$ and $\mathrm{NaOH}$ was conducted at the same conditions and was repeated five times. Figure 12 shows the TC removal using NCPML after five regenerations. It is clear to observe that TC removal was decreased with the number of recycles, but the removal still reached $61 \%$ and $66 \%$ after five regenerations for $\mathrm{HCl}$ and $\mathrm{NaOH}$, respectively. Our results demonstrate that NCPML is not only low-cost but also reusable material.

3.5. Removal of Tetracycline from Wastewater. In this study, we also applied NCPML to treat TC in an actual water sample. The water sample was collected from a fish aquaculture pond in Thai Nguyen Province. The sample was preserved in a polyethylene bottle in a freezer, and then, it was conveyed to the laboratory. We conducted the TC 


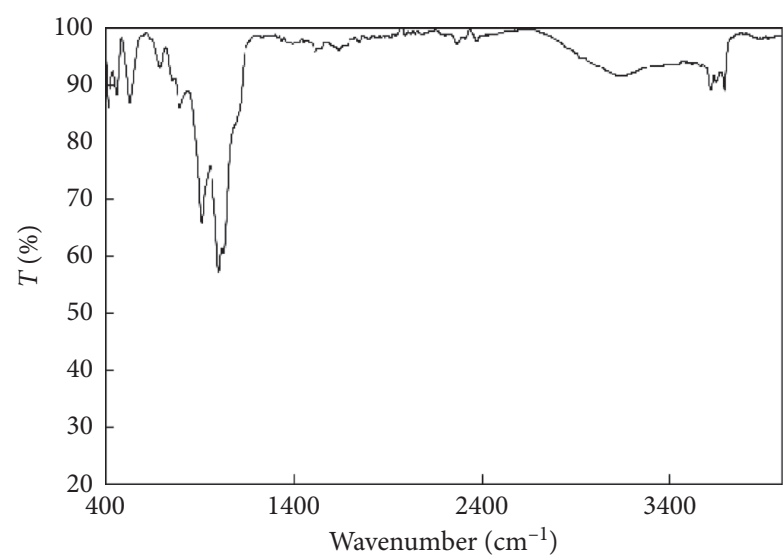

(a)

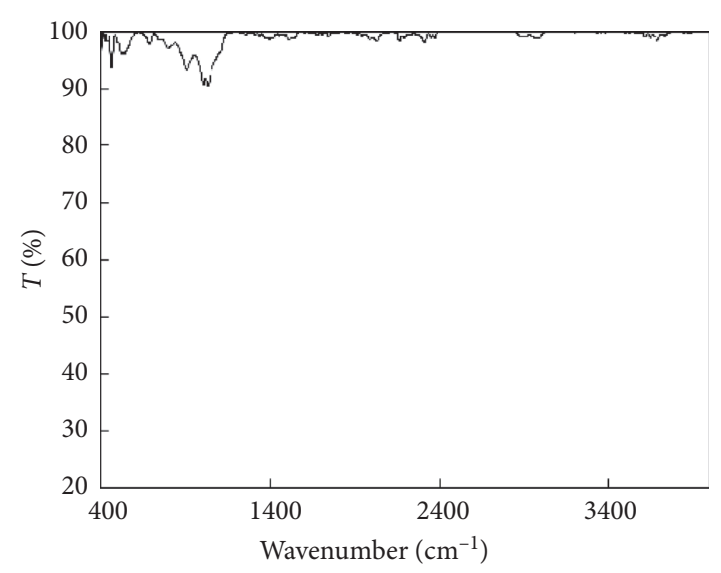

(b)

FIgURE 8: The FT-IR spectra of NCPML before (a) and after (b) TC adsorption in the wavenumber from $400 \mathrm{~cm}^{-1}$ to $4000 \mathrm{~cm}^{-1}$.

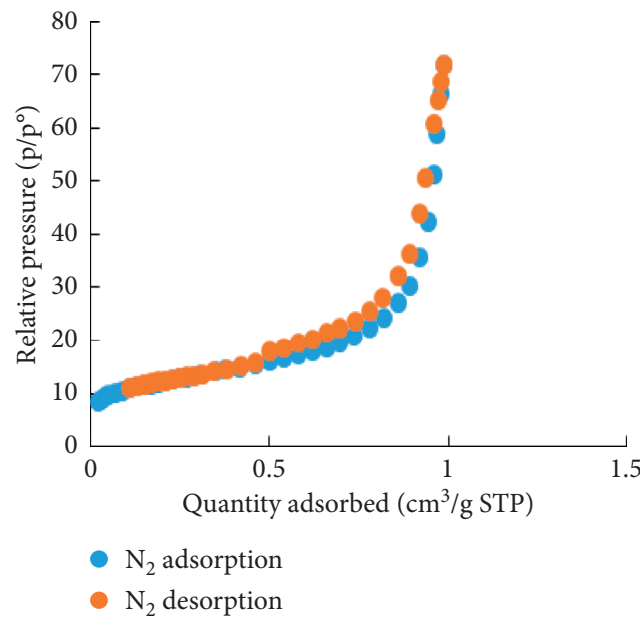

(a)

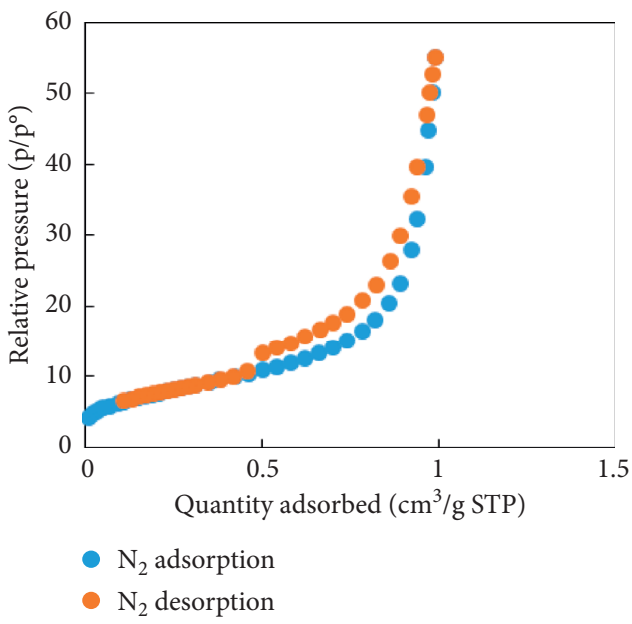

(b)

FIGURE 9: Nitrogen adsorption-desorption isotherms on NCPML before (a) and after (b) TC adsorption.

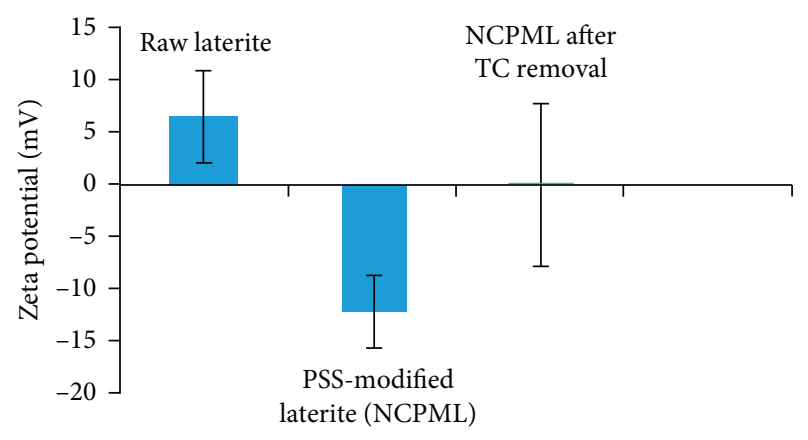

FIGURE 10: The $\zeta$ potential of laterite soil and PSS-modified laterite (NCPML) and NCPML after TC adsorption ( $\mathrm{pH} 4)$.

removal in the sample within 2 days. The TC removal from the sample was carried out at $\mathrm{pH} 4$ and contact time $180 \mathrm{~min}$. The UV-Vis spectrum of TC antibiotic in the sample before
TABle 2: Parameters of adsorption kinetics of TC onto NCPML.

\begin{tabular}{lcccc}
\hline Kinetic model & Parameters & \multicolumn{3}{c}{ TC concentration } \\
& & 10 & 25 & 50 \\
\hline \multirow{3}{*}{ Pseudo-first-order } & $q_{e}(\mathrm{mg} / \mathrm{g})$ & 0.66 & 1.28 & 1.81 \\
& $k_{1, k}(1 / \mathrm{min})$ & 0.001 & 0.001 & 0.001 \\
& $R^{2}$ & 0.826 & 0.830 & 0.845 \\
\hline \multirow{3}{*}{ Pseudo-second-order } & $q_{e}(\mathrm{mg} / \mathrm{g})$ & 1.81 & 3.56 & 5.25 \\
& $k_{2, k}(\mathrm{~g} / \mathrm{mg} \cdot \mathrm{min})$ & 0.038 & 0.020 & 0.015 \\
& $R^{2}$ & 0.992 & 0.995 & 0.996 \\
\hline
\end{tabular}

and after treatment as well as before and after adding TC standards using NCPML is shown in Figure 13. The TC absorbance at a wavelength of $277.4 \mathrm{~nm}$ deeply decreases because of the influence of various factors in actual water during the adsorption process.. By calculation, the TC removal efficiencies reached $81 \%, 78 \%$, and approximately 


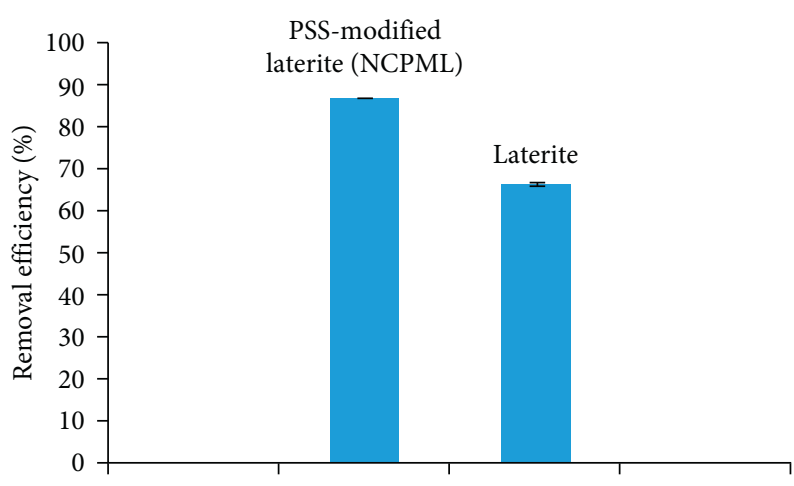

FIGURE 11: Removal efficiency of TC onto laterite with and without modification by PSS. Error bars show standard deviation of three replicates.

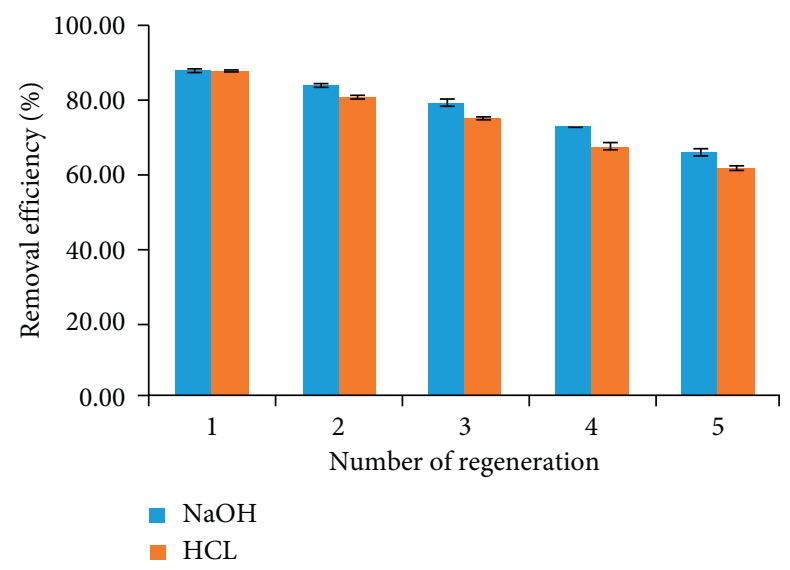

FIGURE 12: The removal of TC using NCPML after five regenerations. Error bars show standard deviation of three replicates.

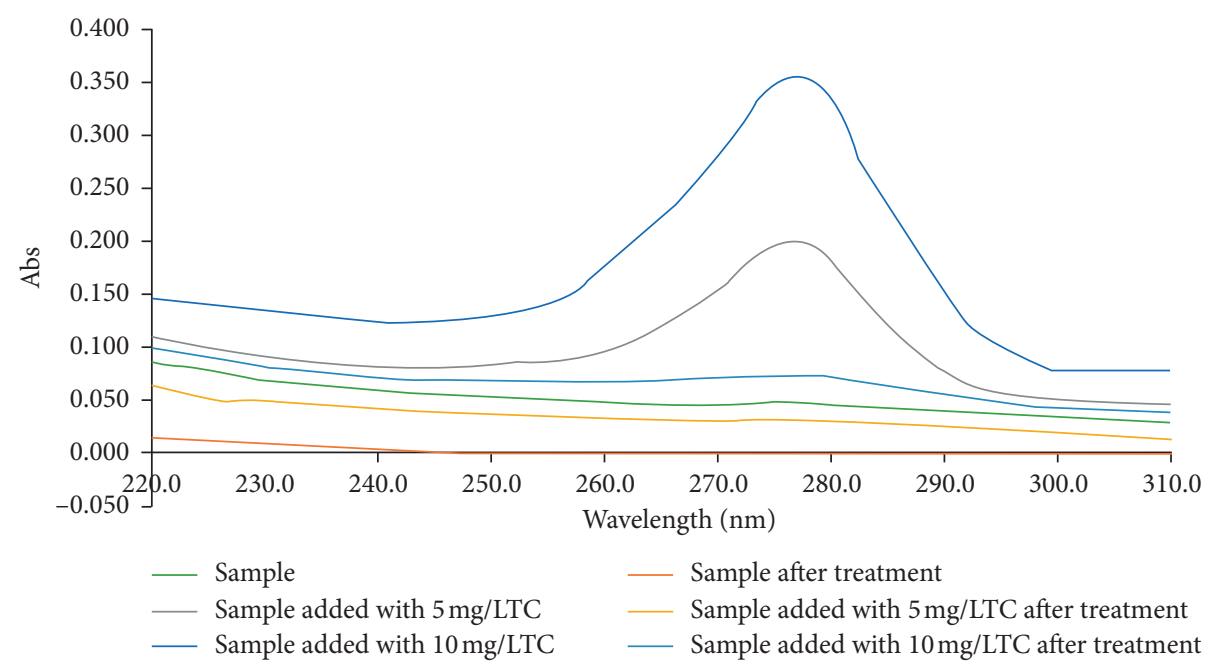

FIGURE 13: The UV-Vis spectrum of TC antibiotic in a water sample collected from aquaculture pond before and after treatment using NCPML. 
94\% for sample added with $5.0 \mathrm{mg} / \mathrm{L}$ TC standard; sample added with $10.0 \mathrm{mg} / \mathrm{L}$ TC standard, and only sample, respectively. The high removal efficiency of approximately $94 \%$ in treating TC in a fish aquaculture pond was obtained. The result indicated that NCPML is eco-effective for treating TC antibiotics from the water environment because of simple modification and high-removal efficiency.

\section{Conclusions}

This study investigated tetracycline removal from aqueous solution using nanocomposite-based PSS-modified laterite (NCPML). Different physicochemical and interfacial methods including $\zeta$ potential, FT-IR, and BET were used to evaluate adsorptive removal of TC using NCPML. The selected conditions for TC removal were found to be $\mathrm{pH} 4$, adsorbent dosage $5 \mathrm{mg} / \mathrm{mL}$, contact time $180 \mathrm{~min}$, and $10 \mathrm{mM} \mathrm{NaCl}$. Adsorption mechanisms of TC onto NCPML were controlled by both electrostatic attractions between negatively charged NCPML surface and the zwitterionic species of TC and nonelectrostatic interactions. Adsorption isotherms of TC onto NCPML were in accordance with the Langmuir model while adsorption kinetics agreed well with the pseudo-second-order model. The TC removal using NCPML was obtained above $66 \%$ after five recycles. A highremoval efficiency of TC in a real water sample collected from a fish aquaculture pond using NCPML reached approximately $94 \%$. This work reveals that NCPML is a novel and hybrid adsorbent for the removal of antibiotics from the water environment.

\section{Data Availability}

All the data and supporting materials used in this study are included within the article.

\section{Conflicts of Interest}

The authors declare that there are no conflicts of interest regarding the publication of this paper.

\section{Acknowledgments}

This research was funded by the Thai Nguyen University of Education (TNUE) under project number CS.2020.01.

\section{References}

[1] A. Radian and Y. G. Mishael, "Characterizing and designing polycation-clay nanocomposites as a basis for imazapyr controlled release formulations," Environmental Science \& Technology, vol. 42, no. 5, pp. 1511-1516, 2008.

[2] H. T. Ha, N. T. Huong, L. L. Dan, N. D. Tung, V. B. Trung, and T. D. Minh, "Removal of heavy metal ion using polymerfunctionalized activated carbon: aspects of environmental economic and chemistry education," Journal of Analytical Methods in Chemistry, vol. 2020, Article ID 8887488, 13 pages, 2020.

[3] H. T. Ha, N. T. Huong, B.-K. Lee et al., "Ternary magnetic polymer cross-coupled in $[\gamma$-APTES]-dispersion to remove azole compound: economic research and educational policy management," Research on Chemical Intermediates, vol. 46, no. 11, pp. 5023-5048, 2020.

[4] N. Bleiman and Y. G. Mishael, "Selenium removal from drinking water by adsorption to chitosan-clay composites and oxides: batch and columns tests," Journal of Hazardous Materials, vol. 183, no. 1-3, pp. 590-595, 2010.

[5] A. Radian, D. Michaeli, C. Serban, R. Nechushtai, and Y. G. Mishael, "Bioactive apo-ferredoxin-polycation-clay composites for iron binding," Journal of Materials Chemistry, vol. 20, no. 21, pp. 4361-4365, 2010.

[6] I. Gardi, S. Nir, and Y. G. Mishael, "Filtration of triazine herbicides by polymer-clay sorbents: coupling an experimental mechanistic approach with empirical modeling," Water Research, vol. 70, pp. 64-73, 2015.

[7] M.-Y. Chang and R.-S. Juang, "Adsorption of tannic acid, humic acid, and dyes from water using the composite of chitosan and activated clay," Journal of Colloid and Interface Science, vol. 278, no. 1, pp. 18-25, 2004.

[8] S. A. El-Korashy, K. Z. Elwakeel, and A. A. El-Hafeiz, "Fabrication of bentonite/thiourea-formaldehyde composite material for $\mathrm{Pb}(\mathrm{II}), \mathrm{Mn}(\mathrm{VII})$ and $\mathrm{Cr}(\mathrm{VI})$ sorption: a combined basic study and industrial application," Journal of Cleaner Production, vol. 137, pp. 40-50, 2016.

[9] S. Wu, X. Zhao, Y. Li et al., "Adsorption of ciprofloxacin onto biocomposite fibers of graphene oxide/calcium alginate," Chemical Engineering Journal, vol. 230, pp. 389-395, 2013.

[10] T. D. Nguyen, H. B. Le, T. O. Dong, and T. D. Pham, "Determination of fluoroquinolones in pharmaceutical formulations by extractive spectrophotometric methods using ionpair complex formation with bromothymol blue," Journal of Analytical Methods in Chemistry, vol. 2018, Article ID 8436948, 11 pages, 2018.

[11] J. J. Mathers, S. C. Flick, and L. A. Cox, "Longer-duration uses of tetracyclines and penicillins in U.S. food-producing animals: indications and microbiologic effects," Environment International, vol. 37, no. 5, pp. 991-1004, 2011.

[12] M. H. Nguyen, T. D. Pham, T. L. Nguyen et al., "Speciation analysis of arsenic compounds by HPLC-ICP-MS: application for human serum and urine," Journal of Analytical Methods in Chemistry, vol. 2018, Article ID 9462019, 8 pages, 2018.

[13] N. Liu, M.-x. Wang, M.-m. Liu et al., "Sorption of tetracycline on organo-montmorillonite," Journal of Hazardous Materials, vol. 225-226, pp. 28-35, 2012.

[14] P. A. Blackwell, P. Kay, and A. B. A. Boxall, "The dissipation and transport of veterinary antibiotics in a sandy loam soil," Chemosphere, vol. 67, no. 2, pp. 292-299, 2007.

[15] S. Kim and D. S. Aga, "Potential ecological and human health impacts of antibiotics and antibiotic-resistant bacteria from wastewater treatment plants," Journal of Toxicology and Environmental Health, Part B, vol. 10, no. 8, pp. 559-573, 2007.

[16] R. Daghrir and P. Drogui, "Tetracycline antibiotics in the environment: a review," Environmental Chemistry Letters, vol. 11, no. 3, pp. 209-227, 2013.

[17] R. A. Figueroa and A. A. MacKay, "Sorption of oxytetracycline to iron oxides and iron oxide-rich soils," Environmental Science \& Technology, vol. 39, no. 17, pp. 6664-6671, 2005.

[18] X. Song, D. Liu, G. Zhang, M. Frigon, X. Meng, and K. Li, "Adsorption mechanisms and the effect of oxytetracycline on activated sludge," Bioresource Technology, vol. 151, pp. 428431, 2014.

[19] Y. Sun, Q. Yue, B. Gao et al., "Preparation of activated carbon derived from cotton linter fibers by fused $\mathrm{NaOH}$ activation and its application for oxytetracycline (OTC) adsorption," 
Journal of Colloid and Interface Science, vol. 368, no. 1, pp. 521-527, 2012.

[20] C. Wang, X. Pan, Y. Fan, Y. Chen, and W. Mu, "The oxidative stress response of oxytetracycline in the ciliate Pseudocohnilembus persalinus," Environmental Toxicology and Pharmacology, vol. 56, pp. 35-42, 2017.

[21] C. Zhao, H. Deng, Y. Li, and Z. Liu, "Photodegradation of oxytetracycline in aqueous by $5 \mathrm{~A}$ and $13 \mathrm{X}$ loaded with $\mathrm{TiO}_{2}$ under UV irradiation," Journal of Hazardous Materials, vol. 176, no. 1-3, pp. 884-892, 2010.

[22] T.-H. Le, C. Ng, N. H. Tran, H. Chen, and K. Y.-H. Gin, "Removal of antibiotic residues, antibiotic resistant bacteria and antibiotic resistance genes in municipal wastewater by membrane bioreactor systems," Water Research, vol. 145, pp. 498-508, 2018.

[23] N. H. Tran, H. Chen, M. Reinhard, F. Mao, and K. Y.-H. Gin, "Occurrence and removal of multiple classes of antibiotics and antimicrobial agents in biological wastewater treatment processes," Water Research, vol. 104, pp. 461-472, 2016.

[24] N. H. Tran and K. Y.-H. Gin, "Occurrence and removal of pharmaceuticals, hormones, personal care products, and endocrine disrupters in a full-scale water reclamation plant," Science of the Total Environment, vol. 599-600, pp. 1503-1516, 2017.

[25] F. Belaib, M. Azzedine, B. Boubeker, and M. AbdeslamHassen, "Experimental study of oxytetracycline retention by adsorption onto polyaniline coated peanut shells," International Journal of Hydrogen Energy, vol. 39, no. 3, pp. 15111515, 2014.

[26] L. Huang, Y. Sun, W. Wang, Q. Yue, and T. Yang, "Comparative study on characterization of activated carbons prepared by microwave and conventional heating methods and application in removal of oxytetracycline (OTC)," Chemical Engineering Journal, vol. 171, no. 3, pp. 1446-1453, 2011.

[27] S. Wang and H. Wang, "Adsorption behavior of antibiotic in soil environment: a critical review," Frontiers of Environmental Science \& Engineering, vol. 9, no. 4, pp. 565-574, 2015.

[28] W. Cai, X. Weng, and Z. Chen, "Highly efficient removal of antibiotic rifampicin from aqueous solution using green synthesis of recyclable nano- $\mathrm{Fe}_{3} \mathrm{O}_{4}$," Environmental Pollution, vol. 247, pp. 839-846, 2019.

[29] E. Yeşilova, B. Osman, A. Kara, and E. Tümay Özer, "Molecularly imprinted particle embedded composite cryogel for selective tetracycline adsorption," Separation and Purification Technology, vol. 200, pp. 155-163, 2018.

[30] M. B. Ahmed, J. L. Zhou, H. H. Ngo, and W. Guo, “Adsorptive removal of antibiotics from water and wastewater: progress and challenges," Science of The Total Environment, vol. 532, pp. 112-126, 2015.

[31] T. M. V. Ngo, T. H. Truong, T. H. L. Nguyen et al., "Surface modified laterite soil with an anionic surfactant for the removal of a cationic dye (crystal violet) from an aqueous solution," Water, Air, \& Soil Pollution, vol. 231, p. 285, 2020.

[32] T. D. Pham, H. H. Nguyen, N. V. Nguyen et al., "Adsorptive removal of copper by using surfactant modified laterite soil," Journal of Chemistry, vol. 2017, Article ID 1986071, 10 pages, 2017.

[33] T. D. Pham, T. T. Pham, M. N. Phan, T. M. V. Ngo, V. D. Dang, and C. M. Vu, "Adsorption characteristics of anionic surfactant onto laterite soil with differently charged surfaces and application for cationic dye removal," Journal of Molecular Liquids, vol. 301, p. 112456, 2020.

[34] A. V. Delgado, F. González-Caballero, R. J. Hunter, L. K. Koopal, and J. Lyklema, "Measurement and interpretation of electrokinetic phenomena," Journal of Colloid and Interface Science, vol. 309, no. 2, pp. 194-224, 2007.

[35] I. Langmuir, "The adsorption of gases on plane surfaces of glass, mica and platinum," Journal of the American Chemical Society, vol. 40, no. 9, pp. 1361-1403, 1918.

[36] H. M. F. Freundlich, "Über die adsorption in Lösungen," Zeitschrift für Physikalische Chemie, vol. 57A, p. 385, 1906.

[37] W.-R. Chen and C.-H. Huang, "Adsorption and transformation of tetracycline antibiotics with aluminum oxide," Chemosphere, vol. 79, no. 8, pp. 779-785, 2010.

[38] M. E. Parolo, M. C. Savini, J. M. Vallés, M. T. Baschini, and M. J. Avena, "Tetracycline adsorption on montmorillonite: $\mathrm{pH}$ and ionic strength effects," Applied Clay Science, vol. 40, no. 1-4, pp. 179-186, 2008.

[39] Z. Li, L. Schulz, C. Ackley, and N. Fenske, "Adsorption of tetracycline on kaolinite with $\mathrm{pH}$-dependent surface charges," Journal of Colloid and Interface Science, vol. 351, no. 1, pp. 254-260, 2010.

[40] E. P. Barrett, L. G. Joyner, and P. P. Halenda, "The determination of pore volume and area distributions in porous substances. I. Computations from nitrogen isotherms," Journal of the American Chemical Society, vol. 73, no. 1, pp. 373-380, 1951.

[41] Y. Huang, A. Yamaguchi, T. D. Pham, and M. Kobayashi, "Charging and aggregation behavior of silica particles in the presence of lysozymes," Colloid and Polymer Science, vol. 296, no. 1, pp. 145-155, 2018.

[42] M. Kobayashi, "Electrophoretic mobility of latex spheres in the presence of divalent ions: experiments and modeling," Colloid and Polymer Science, vol. 286, no. 8-9, pp. 935-940, 2008.

[43] T. D. Pham, T. U. Do, T. T. Pham et al., "Adsorption of poly(styrenesulfonate) onto different-sized alumina particles: characteristics and mechanisms," Colloid and Polymer Science, vol. 297, no. 1, pp. 13-22, 2019.

[44] T. D. Pham, M. Kobayashi, and Y. Adachi, "Adsorption characteristics of anionic azo dye onto large $\alpha$-alumina beads," Colloid and Polymer Science, vol. 293, no. 7, pp. 1877-1886, 2015. 